\title{
Teaching Anger
}

\section{PES 2020 Presidential Address}

\author{
Cris Mayo \\ University of Vermont
}

Some of our last few presidential addresses have focused on the feelings of the times-Kathy Hytten, at the American Educational Studies Association, encouraging activist hope and community, Barb Stengel discussing the fear that structures our conditions but getting us to move beyond it and Frank Margonis criticizing those senses of responsibility that reinforce neocolonization. ${ }^{1}$ Perhaps not surprisingly, I'm going to look at anger as a method of teaching and learning, a way to signal the necessity for change, and a way to demand attention. Anger may seem an unlikely bridge, but the method of anger I will be discussing is a kind of difficult invitation to move anger beyond affect in much the same way Hytten moves hope into action. If we think of anger as a method of attentiveness in a context where not enough people are attentive, anger is itself not a problem. We ought to be angry, we ought to be agitating the rethinking of those who are passively inattentive around us. As the saying goes, if you're not angry, you're not paying attention.

I think lately anger has gotten short shrift because of how much destructive rage is circulating methodically but not so much intent on deepening thought. My first step distinguishes anger from what seems to cause most consternation about anger and what I think is not anger per se but a particular end state or a dull, vicious, blustering, verging into vengeance. Vengeance seems to me to be the target of much critique of anger, not anger itself, or at least not the motivating anger I'm discussing here. I think we should keep the anger's intensity of focus, both its abrupt intervention, and its simmering attentiveness. That world-shifting/point-of-view-altering quality of anger can help thought more quickly and intensely both by its dramatic signaling function and by its potential to meet someone less inclined to think kindly on their own ground. Further, I think anger is useful because the transformative educational imperatives many of us have all been advocating for often push too quickly 
into calm and don't stay with the anger of frustration, the anger of accusation, or our anger at insufficiency. Instead we hurry through transformation to a hoped-for resolution. We reasonably dodge stultifying guilt but don't live in the disruptive dissatisfaction of methodical anger long enough. Either encouraged to placate those with whom we're angry or just dim our grievances, we move on before our anger gets called out as the problem itself. "I can't hear you through your anger" is a strategy of ignoring anger that makes our angry response to a problem become itself the problem, eclipsing the problem that started it. This kind of double bind is irritating in many interactions, whether they be those where anger erupts or those where the demand for civility first undercuts the ability of those who have no way to disrupt civil ignoring in order to be heard. It may be that the fearful or disdainful reaction to anger is instead an indication that anger was warranted. Anger is an amplification of the desire that another pay attention to a problem they are ignoring.

\section{STAYING WITH THE RUSH BUT LEAVING THE VENGEANCE}

Anger is of course not without its critics. Seneca says, "Anger's in a hurry." Anger's rush to vengeance does not allow rational thought to intervene and temper anger's viciousness. Even in its mildest form, he thinks anger wreaks vengeance by seeking to stop conversation; anger lashes out at pain with no intention to repair or improve he says. ${ }^{3}$ He suggests that anger is "too hasty and witless." "Martha Nussbaum suggests that a short moment of anger may help lead to transformation but then we must quickly move into love lest anger have a chance to move into vengeance. In her analysis, anger remains defined by payback. ${ }^{5}$

But Seneca's focus on vengeance and Nussbaum's focus on payback only describes the endpoint of certain kinds of anger, not a definitional requirement for anger itself. By defining anger solely by its worst possible outcome, their conception of anger is limited. Anger may have the quality of being rushed into a response one might prefer to not have. But that sense of rush does not necessarily come from the person having a sense of urgency or doing damage as a result of their misguided urgency. Their feeling of the need to rush or even to incite someone else's attention may come from the situation that requires 
urgent response. Seneca's conflation of anger with vengeance sets Nussbaum on a path of argument that puts the passionate rush of anger together with the viciousness of revenge to determine that these two, necessarily together, are the wrong approach. But Seneca approves of what might seem to us as viciousness, like mass killing, if it is done dispassionately. Vengeance, for Seneca, is problematic only because of its passion; what we would consider to be inhumane acts themselves are a problem for him if they are undertaken coolly and rationally. By not untangling passionate cruelty with the disruption of anger, Nussbaum, I think, overcompensates for damaging vengeance and, as a result, rushes into forgiveness too quickly. Since the focus of her critique of anger is its-really vengeance's - backward-looking spiral of revenge, her solution is forward-looking forgiveness, with only a short stop in what she calls Transition-Anger. ${ }^{6}$

In the kind of anger as a teaching method I'm suggesting, anger signals the lack of relationship and also some tentative indication of a hope for connection. Anger signals that some people have the inability to be willing to either pay attention or attempt to see the anger-motivating situation from another's perspective. Audre Lorde keeps anger as a necessary response to such unresponsiveness:

My response to racism is anger. I have lived with that anger, ignoring it, feeding upon it, learning to use it before it laid my visions to waste, for most of my life. Once I did it in silence, afraid of the weight. My fear of anger taught me nothing. Your fear of that anger will teach you nothing, also. Women responding to racism means women responding to anger; Anger of exclusion, of unquestioned privilege, of racial distortions, of silence, ill-use, stereotyping, defensiveness, misnaming, betrayal, and co-optation. ${ }^{7}$

Lorde wants recognition for her methods of anger against racism and also encourages, in this case, white women to be able to respond to anger. Anger in its simplest form may simply contain these two steps: not wanting something to be the way it is and wanting to stop it from happening again. ${ }^{8}$

Linda Grasso suggests that we ought to consider anger as "a method 
of reading," one that takes into account the ways that, in her focus on diverse women's literature, women have been pushed away from expressing anger too directly. ${ }^{9}$ Anger, in other words, has been all around us but by focusing on anger in only its most extreme state, defined by a destructive endpoint of vengeance, anger of those who are not sufficiently recognized or whose anger is not recognized goes unnoticed. Attentiveness to anger, then, may also mean attentiveness to the anger of marginalized people who can only rarely clearly express their anger. Anger, if visible, she suggests, is a signal that change needs to happen and that someone who usually ignores the concerns of the subordinate ought to take notice. ${ }^{10}$ Maxime Lepoutre makes a similar point in advocating for how anger can redirect the perennially inattentive. She says:

conveying anger to one's listeners is epistemically valuable in two respects: first, it can direct listeners' attention to elusive morally relevant features of the situation; second, it enables them to register injustices that their existing evaluative categories are not yet suited to capturing. Thus, when employed skillfully, angry speech promotes a greater understanding of existing injustices. This epistemic role is indispensable in highly divided societies, where the injustices endured by some groups are often invisible to, or misunderstood by, other groups. ${ }^{11}$

It is possible that the rage of those in dominant positions stands in for all anger for both Seneca and Nussbaum. That those in dominant positions wreak havoc with their intemperate cruelty makes anger seem definitionally violent and vengeful. But learning to see the everyday little angers that seek to teach can help to re-organize how people think of themselves and the world. Jessica Moss argues that "it is a powerful motivational force in those who are not virtuous; unlike appetite it can be shaped and guided to lead those who are not virtuous toward virtue."12 In other words, anger may help those who willfully continue to ignore injustice, whether through their dominant position and/or experiential habits to not see, to be pushed to look more thoughtfully on the things they would prefer not to. 


\section{ANGER AND ITS PROBLEMS}

Advocating for and recuperating anger is not without its problems. One problem may be that, if done right, anger really isn't even anger anymore. For Aristotle, anger done correctly is good-temperedness:

The man who is angry at the right things and with the right people, and, further, as he ought, when he ought, and as long as he ought, is praised. This will be the good-tempered man, then, since good temper is praised. For the good-tempered man tends to be unperturbed and not to be led by passion, but to be angry in the manner, at the things, and for the length of time, that the rule dictates; but he is thought to err rather in the direction of deficiency; for the good-tempered man is not revengeful, but rather tends to make allowances. ${ }^{13}$

Aristotle removes the sense of disruption I want to keep and also only allows those of the best sort and temperament to have the right sort of anger. Anger is instead a call to see differently, raised to a higher level of intensity because its audience has shown no interest. As Lorde puts it, "Anger is loaded with information and energy." ${ }^{14}$ But too often that information is ignored and a fear of anger used to excuse that ignorance. Anger, says Lorde, is a response to that loss of connection: "Anger is a grief of distortions between peers, and its object is change." 15 Albeit not directly addressing Lorde, Nussbaum suggests that an anger that does not want "payback" is no anger at all—it is instead simply grief. ${ }^{16}$ But I'm concerned that grief, without the continuing relationality and responsibility demanded by anger, does not go far enough. "I'm sorry you feel that way" leaves in place the problem and takes the consoler out of the circuit of the problem.

Perhaps the reason that many of us do not want to reckon with anger is that anger worries us, whether we are the angry person or the person whose practices are eliciting anger. We may not want to see that we have used anger's potential badly and disavow anger rather than face it. Barbara Deming discusses this tension in her struggle with anger and nonviolence. Pacifists so strongly 
disavow their anger that others have a suspicion about the purity of those who advocate nonviolence. Something in that determination to not be angry seems so implausible that the convictions of the nonviolent become entirely dubious. No one can not have anger, she thinks. She recalls another activist pushing against nonviolence and reminding her that protests are literally charged with disturbing the peace. Disruption is the point. Her solution distinguishes between a violent anger we don't want and a generative anger. Generative anger says "this must change." 17

Anger at one part of a problem is also not enough: anger should invite reckoning with other angers. Converging, intersecting, and divergent angers push at the limitation of seeing the problem through one's own sense of experience and, ideally, move into solidarities of anger. Anger is our method; it is the jolting, painful break in routine. In philosophy of education, we often want that jolt. As Deborah Kerdeman has noted, this sense of being pulled up short can move us beyond the frustration caused by our own misses and sometimes this requires someone else with a potentially more urgent connection to an issue, like white supremacy, push us into a reconsideration of our own position. ${ }^{18}$ We might also become our own torpedo fish, to actively take on what others try to push us to think about, as Ann Diller has suggested. ${ }^{19}$ Our own sting should engender a response and move us out of the ignorance we didn't know we had. Being found out, by ourselves or others, in our ignorance is embarrassing, yes, but it is also frustrating, and frustration is a form of anger at ourselves. We shake in disbelief that we could be so stupid. We rage at ourselves. We are literally beside ourselves. If this is a quick blush at our mistake or an internal shaking, we occupy a critical distance. Megan Boler's discussion of students angrily resisting social justice curricula suggests that those students, especially resistant female or racialized students, may be responding angrily to the shatter of their strategies for survival and fear "annihilation" if their conservative worldviews are challenged. ${ }^{20}$ Boler advocates for a pedagogy of discomfort-and some of that discomfort will be anger-because "education is not effective if it is not combative and alienating." ${ }^{21}$ While she cites Mark Epstein calling anger a "perversion of love," 22 I don't think that's quite right. Anger is our method of 
getting beyond where we are and in its best iteration organizes against wrong.

A reasonable objection is that anger is epistemologically dangerous: it can lead to a raging inability to see straight. But what leads to anger may be that one was trying to see straight and that straightness didn't work to describe one's situation. Anger, one might object, is a deflection of responsibility to think carefully: instead one rages at the conditions that require intervention. I think this objection too is an objection to rage and vengeance, not the method of anger itself. Anger gives us a reason to make judgments and to see a context or issue we'd ignored differently. In discussing racism, James Baldwin observes:

To be a Negro in this country and relatively conscious, is to be in a rage almost all the time. So that the first problem is how to control that rage so it won't destroy you. Part of the rage is this: it isn't only what is happening to you, but it's what's happening all around you all of the time, in the face of the most extraordinary and criminal indifference, the indifference and ignorance of most white people in this country. Now, since this [is] so, it's a great temptation to simplify the issues under the illusion that if you simplify them enough, people will recognize them; this illusion is very dangerous because that isn't the way it works. ${ }^{23}$

One might also object that by staying in anger we are binding ourselves to the conditions that should be dissatisfying (or is even, as Baldwin points out, damaging): anger is just another form of resentment. But if anger leads us to judgment and judgment to organizing for change, anger's function is political and the scene of our politics can potentially move us in new directions, unless we're perpetually hushed, told not to be angry, and so retreat into not seeing or to giving up critical judgment. Anger keeps us watchful, too, unwilling to go through that again.

Anger can also help us to plan not to participate in the conditions that generate anger. In a number of my classes, I ask students to write autobiographies, thinking through when various ascribed identities first became apparent to them. Did they notice them as invitations to join a community? 
Times when limitations were put on them? Obstacles or possibilities? What was their response? In many of their essays, they recount anger; sometimes that anger has a long duration and gives them, at least in the context of a class assignment, a decision to not enact the same restrictions on their future students that they experienced in schools, families, or communities. Other angers are harder though, when students in another assignment put their memories of their education into conversation with research about their schools. They look at redlining practices in their district and patterns of internal racial segregation in their schools. Sometimes the anger is internal: their memories were wrong. "There were no Black kids in my high school" turns into "The classes I was in, the hallways I walked down, were segregated. I never saw Black students, Latino/a/x students." In what Audrey Thompson has called "listening at an angle," ${ }^{24}$ students who stay with the discomfort of listening to classmates who recount exclusions in public education that they hadn't experienced, who learn from youth of color or young people with disabilities in after-school programs, and who re-approach their own educational pasts, also verge into anger at what they hadn't noticed or what hadn't been addressed in their schools.

\section{DEFLECTION}

Using the Truth and Reconciliation process in South Africa as an example of revolutionary justice without anger, Nussbaum notes that no one had to express contrition or promise to not do whatever racist violence again. She approves this procedural avoidance of "debasement." 25 Her "Transition-Anger" seeks to improve the world not lead to self-corrosion or vengeance, but while avoiding punishment may help to unite a divided populace, avoiding melioration of unjust conditions potentially also maintains those divisions. Because she wants calling to account to move to future-orientation but has not provided a way to address loss here and now or interrupt patterns continued from the past. But we're also here and now, in anger, and too much of that present anger is either ignored or literally out of view because of structuring practices of reconciliation.

In the interview with James Baldwin quoted earlier, Lorraine Hansberry describes why Faulkner has never written a compelling black character: 
William Faulkner has never sat in a Negro home where there were all Negroes. It is physically impossible. He has never heard the nuances of hatred, of total contempt from his most devoted servant and his most loved friend, although she means every word when she's talking to him, and will tell him profoundly intimate things. But he has never heard the truth of it. ${ }^{26}$

Hansberry says this in the midst of arguing with white interviewers that they don't understand Black people and is repeatedly interrupted by them and corrected by them. She repeatedly apologizes to them (they aren't listening to what she says) but nonetheless points out the same circuit of ignorance replicated in their conversation and in the work of white authors too. Her point was both that they were not listening when she was telling them what was wrong, in their space, but also how hard it was for them to listen without having been in the closer intimate spaces in which those angers circulate regularly, not as a special occasion and not as occasion, seemingly, that will ever demand their response. Sara Ahmed describes this sort of scene as "a result of being in spaces that are lived as white, the spaces into which white bodies can sink." ${ }^{27}$ Hansberry does not want her white interlocutors to be able to sink back into discussions that won't allow the crackle of her anger to be noticed.

Other forms of not noticing have to blank out entire landscapes. In her ethnography Strangers in their own land: anger and mourning on the American Right, Arlie Hochschild talks with people whose property and lives have been damaged or destroyed by industrial waste and finds their anger is not directed at those causing the problems. ${ }^{28}$ Their anger follows the lines of conservatism, deflecting blame for devastation onto outsiders, immigrants, changes in social practices, anything but the palpable source of blight on their property and in their environs. Even while they see neighbors abandoning houses in neighborhoods that are no longer habitable, their anger deflects onto targets other than the industries responsible for the wreckage. This deflection, as Barbara Applebaum reminds us, needs to be understood as discursive, reconfirming ignorances that have constitutive power. ${ }^{29}$ They know they live in cancer clusters, they have 
lost relatives, but the real challenges, they think, are elsewhere: the loss values in our society and so on. Even as their discourses are mobilized and enjoined to redescribe the scene of environmental destruction as something else, feelings maybe that might have gone into addressing their close-up losses, track with those discourses off into other problems. Is this the fear of critical anger that Lorde discussed above, a confirmation of core beliefs in contradiction to what is indisputably the root of the damage these homeowners can see for themselves? Does anger become a tangle of confirmation bias or does anger, as an affect but not a method, emerge but not find what Aristotle would possibly suggest is its right purpose and target? Or am I just angry at them for not seeing what seems obvious? Would they be angry at me for not seeing that they needed those polluting industries to get where they got today?

Not long ago, I was listening to a young man on West Virginia public radio describe why, even when the coal industry in West Virginia is dying and rates of black lung are on the rise again as deregulation takes hold again, he was determined to finish his training and get a job in underground mining. His family needed his income to help his uncle who was dying of black lung disease. There may be no point for him to be angry at where he is because there is no apparent way for him to be somewhere else. Easier then to be angry at something distant, like the call to replace mining with solar farms or the specter of outsiders coming into the state. This deferral of direct anger to the right target may itself be a kind of mourning for his inability to enact a right kind of anger that brings in new possibilities. His anger has a method, but it can only face part of where we are now without a context of organizing for something better.

In "Mourning and Militancy," Douglas Crimp takes up this problem of mourning to push away from a subject-centered reconnection to a lost object. ${ }^{30}$ Militancy, he suggests, is linked to mourning and the implicit presumption that mourners should eventually turn away from the lost object and return to normalcy. He notes, gay men have never been normal. The resolution of queer anger is no different: there is no normal state to return to. If queers, transpeople, and, for that matter, any marginalized people have come up understanding that they were always outside and even if they get mad enough to want to hope for 
something better and even more if they make incremental progress, the past of non-normalcy and the seemingly constant threat or reality of backlash forecloses any permanent move out of practices of watchful anger. At the same time, we're all being watchful, other more normatively situated people are satisfied change has happened and endeavor to keep us temperate in our responses to things that from our perspective haven't changed.

Crimp discusses this in the context of silences around AIDS deaths, arguing that such silencing has to turn to anger in new ways of mourning. Militancy keeps the connection to those lost, to losses in general, and directs our attention to what changes for the better. In his example, the push and pull of mourning is both the identification with those who have died from HIV, the uncertainty of militants about their own future in relation to HIV, and the potential for survivor guilt. Crimp's example is of course quite specific, but I think bears thinking about in terms of the ways we are watchful for returns and repeats of bias-related experiences. We don't mourn, we organize, and if we don't organize, we at least stay in a low-level state of awareness of the next potential slight, keeping our anger at the ready to intervene and move us away from injury.

\section{TEMPERING}

Organizing and learning together, I think, are where the tempering anger happens. Tempering is both a process of strengthening and a process of realignment. Anger moves away from just our single perspective into alliance, the present, and the future.

We may be coming to some confluence of anger about misogynies and anti-trans bias, getting to a point where movements, communities, and our classes can talk about the persistence of sexism and misogyny, the particularities of intersecting violence experienced by women of color, and the pervasive bias against transpeople, especially racist trans misogyny, and also recognize the concerted effort to remove reproductive choice from all women and all families. The unfinished work of feminisms is frustrating to women of all sorts who feel they have yet to be able to occupy public space, experience reproductive 
freedom, or even work in a place that takes childcare needs seriously. Even in conversations with self-identified conservative women there seems to be some feeling of common cause with transpeople. There's a meme, the one with the young person beholding a butterfly, that reads "Me, a transgirl," the butterfly reads "misogyny," and the bottom caption reads "is this gender affirmation?" that gets to the recognition of that unfinished business of feminism and the possibilities of gender-based solidarities. But conservative women with whom I've talked are also perplexed that no one seems to care about their experiences of intimate partner violence, fear of sexual assault and their worries about the sexual exploitation of children. Their problems are mostly coming from inside their own houses but they have the chance to talk about these problems while joining public transphobic demonstrations. Progressives may be rightly angry at conservative white women for voting with their racial or religious issues instead of gender solidarity but those same conservative white women are also angry that they still have to alter their habits of movement to avoid sexual assault and provide comfort to other women who can't escape domestic violence. As much as they are surprised to hear about the pervasiveness of violence against transpeople, so too are transpeople surprised to hear that a major cause of ciswomen seeking emergency medical care are injuries from partner violence. Easier, perhaps, to be angry than to see that other people have good reason to be angry themselves. So understanding our own various angers better may give us a method for understanding the anger of others too. Thinking of anger as a method may help us to trace these strategies of response and thought.

I think teaching in the midst of interconnected angers and criticalities is challenging but keeping at the right kind of anger, at the right kind of targets needs more and more thought and practice. Staying with the anger in the right way is hard. Responding to anger, too, is very difficult. Any of us who read the Chronicle of Higher Education or Insider Higher Education has watched time after time as administrators, even those who are trying, can't quite address the student anger, and situations go further off track. There may be good, defensive reasons for administrators starting their letters to campus with four paragraphs on the value of freedom of speech before getting to some indication 
that white supremacy does not reflect our campus values. But that decision to defend the principled commitment to allowing hate to take the stage before addressing student concerns seems to many of us to miss the occasion. Being with students in anger is also hard. It is tempting to too many of us to want to move onto the constructive part of our conversation, where we're really good at being persuasive, before what has caused their anger has been addressed.

\section{GETTIING OVER IT: ANGER AND FORGIVENESS}

I agree, of course, that there has to be something after anger and something to reset relationships after a problem has been solved. Where Nussbaum and Seneca find anger too quick, though, I'm concerned that we're sometimes pushed to forgive too quickly. After the mass murder of Black parishioners at the Emanuel African Methodist Episcopal Church in Charleston, discussion about the relationship between anger and forgiveness restarted when several relatives of those murdered publicly indicated their forgiveness of the white supremacist who killed their loved ones. Their extension of grace and their determination to not live in anger seemed, to some, to be a welcome contrast to the continuing anger in Ferguson. By rising beyond an act of hate, they honored the memories of their relatives who had committed their lives to love and to a faith that has a core value of redemption. To others, including those who also lost relatives and also had a faith-based response, forgiveness was a too-quick resolution that neglected the continuing problem of white supremacy. ${ }^{31}$ Others saw their decision to forgive the violence of white supremacy as a necessary refusal to be provoked into the race war intended by the white mass murderer and so a tactical decision to meet hate with love.

Forgiveness allows for a return to remembering that community has its own strengths and histories. But those who do not want to forgive point to the unfinished history of racism that has long defined Charleston. In their discussion of the aftermath of the shooting and the documentary about it, Emanuel, Maurice Wallace and Tony Tian-Ren Lin suggest:

Perhaps, the survivors in Charleston who refused to too swiftly pardon the murderer appear to know what those quick to praise the forgiving 
ones do not understand: Forgiveness untethered from justice sanctions the status quo responsible for producing Roof. The forgiveness exalted in [the documentary] "Emanuel" runs the risk of getting entangled in that version that is invented to absolve white Christianity of culpability in the nation's sins against black people. ${ }^{32}$

How does the desire to seek forgiveness from Black people then function not just to reflect (some of their) faith but also to reassure white people of the continuing willingness of Black people not to harbor anger against white supremacy? The push to forgiveness is not the same as people healing their grief through beliefs that sustain them, but too many of us have experienced this push to forgive in more minor situations. Turning away from anger before any positive work is done to mitigate motivating situations potentially stimulates more anger.

\section{GET OVER IT, GET USED TO IT}

This method of anger reminds us of the unfinished businesses of justice. Those of us who have been involved in feminist and more organizing, too, have found ourselves unsurprised that those supposed feminist victories were exaggerated, partial, and fragile: we were told that reproductive freedom will never be seriously challenged, equal pay for equal work is unreasonable because women don't want to work in the same way men do, and so on. And we're angry because there appeared to be some progress toward transgender rights, especially for trans and nonbinary young people who were going to be more consistently covered by Title IX even in the many states without legal protections against discrimination on the basis of gender identity. But that, too, is stalled in many locations. Some of us, too, are just presumed to be angry because we don't uptalk or do other gestures of submission that are expected in almost every kind of interaction.

Anger goes on, too, because it is not noticed. Sometimes it is apparently not even legible when a million women, transpeople, and men express it. ${ }^{33}$ That National Archives, on the occasion of the one hundredth anniversary of 
women's suffrage, recently censored posters from the Women's March in 2017 to diminish the force and target of the marchers' anger. Sometimes we're just angry because of this concerted effort at covering over anger. Learning to stay with anger, to use its rush and method, and to encourage our allies not to so quickly say, "have you thought of $\mathrm{x}$ instead?" are necessary ways for us all to keep going together.

1 Kathy Hytten, American Educational Studies Association Presidential Address, "Cultivating Hope and Building Community: Reflections on Social Justice Activism in Educational Studies," Educational Studies 46, no. 2 (2010), 151-167; Barbara Stengel, “'So Open it Hurts’: Enabling 'Therefore We Can’ in the Dangerous Secure World of Education," Philosophy of Education (2013): 1-15; Frank Margonis, "Opting Out of Neocolonial Relationality," Philosophy of Education (2015): 1-13.

2 Seneca, Anger, Mercy, Revenge, trans. Robert A. Kaster and Martha C. Nussbaum (University of Chicago Press, 2012).

3 Seneca, Anger, Mercy, Revenge, 18:1.

4 Seneca, Anger, Mercy, Revenge, 12:5.

5 Martha C. Nussbaum, Anger and Forgiveness: Resentment, Generosity, Justice (Oxford University Press, 2016); J. R. Averill, Anger and Aggression: An Essay on Emotion (New York: Springer-Verlag, 1982) suggests anger is not a state in and of itself but, among other things, provides a post hoc 
justification for actions like vengeance. In his essay, "Ten Questions About Anger that You May Never Thought to Ask," Averill splits "anger" from "aggression," keeping anger's ability to read social problems separate from aggression's desire to harm (4); in Farzaneh Pablavan, ed., Multiple Facets of Anger: Getting Mad or Restoring Justice (New York: Nova Science, 2011), $1-26$.

6 Nussbaum, Anger and Forgiveness, 35-36.

7 Audre Lorde, “The Uses of Anger: Women Responding to Racism," in Sister Outsider (New York: Ten Speed Press), 124-133.

8 A. Wierzbicka, Emotions across Languages and Cultures: Diversity and Universals (Cambridge University Press, 1999), 287.

9 Linda M. Grasso, Artistry of Anger: Black and White Women's Literature in America, 1820-1860 (Chapel Hill: University of North Carolina Press, 2002), 4.

10 Grasso, Artistry of Anger, 11.

11 Maxime Lepoutre, "Rage Inside the Machine: Defending the Place of Anger in Democratic Speech," Politics, Philosophy and Economics 17, no. 4 (2018): 398-426. 
12 Jessica Moss, "Shame, Pleasure, and the Divided Soul," Oxford Studies in Ancient Philosophy, 29 (2005): 137-170.

13 Aristotle, The Nicomachean Ethics of Aristotle, trans. William David Ross, (1908).

14 Lorde, "The Uses of Anger," 127.

15 Lorde, "The Uses of Anger," 129.

16 Martha C. Nussbaum, “Beyond Anger,” Aeon, https:/ / aeon.co/essays/ there-s-no-emotion-we-ought-to-think-harder-about-than-anger.

17 Barbara Deming, “On Anger,” https://peacenews.info/node/7610/anger $\% \mathrm{EF} \% \mathrm{BB} \% \mathrm{BF}$.

18 Deborah Kerdeman, "Pulled Up Short: Exposing White Privilege," Philosophy of Education (2017): 1-18.

19 Ann Diller, "Facing the Torpedo Fish: Becoming a Philosopher of One's Own Education," Philosophy of Education (1998): 1-9.

20 Megan Boler, "Teaching for Hope: The Ethics of Shattering Worldviews," Discerning Critical Hope in Educational Practices, ed. Vivienne Bozalek, 
Brenda Leibowitz, Ronelle Carolissen, \& Megan Boler (New York: Routledge, 2014), 27.

21 Boler, “Teaching for Hope," 28.

22 Boler, “Teaching for Hope," 28.

23 James Baldwin in "The Negro in American Culture" (interview by Nat Hentoff), CrossCurrents (Summer, 1961): 205.

24 Audrey Thompson, “Listening at an Angle," Philosophy of Education (2010): 1-10.

25 Nussbaum, Anger and Forgiveness, 243.

26 Lorraine Hansberry in "The Negro in American Culture" (interview of James Baldwin, Lorraine Hansberry, \& Langston Hughes by Nat Hentoff), CrossCurrents (Summer, 1961): 217.

27 Sara Ahmed, Queer Phenomenology: Orientations, Objects, Others (Durham, NC: Duke University Press, 2007).

28 Arlie Hochschild, Strangers in Their Own Land: Anger and Mourning on the American Right (Berkeley: University of California Press, 2016). 
29 Barbara Applebaum, "The Importance of Understanding Discourse in Social Justice Education: The Truth and Nothing But the Truth?," Philosophy of Education (2016): 1-14.

30 Douglas Crimp, “Mourning and Militancy,” October 51 (Winter, 1989): $3-18$.

31 Frank Harris III, “Too Soon for Forgiveness in Charleston,” Hartford Courant, July 2, 2015, accessed on Jan. 8, 2020 from https://www.courant. com/opinion/op-ed/hc-op-harris-too-soon-forgiveness-in-charleston-070220150701-column.html.

32 Maurice Wallace and Tony Tian-Ren Lin, 'Like 'Green Book,' the new Charleston church shooting documentary is troubling," Washington Post, 21 June 2019, accessed on Jan. 8, 2020 from https://www.washingtonpost.com/ religion/2019/06/21/like-green-book-new-charleston-church-shooting-documentary-is-troubling/.

33 No forced choice is implied by this list: people are more than one of these. 
